\title{
Alat Pewarna Semi Otomatis Untuk Meningkatkan Produksi Kerajinan Anyaman Purun
}

\author{
Fatma Indriani ${ }^{*}$, Mohammad Mahfuzh Shiddiq \\ Prodi Ilmu Komputer, FMIPA Universitas Lambung Mangkurat \\ Jl. A. Yani Km 36, Banjarbaru, Kalimantan Selatan \\ $1^{*}$ f.indriani@ulm.ac.id \\ Prodi Matematika, FMIPA Universitas Lambung Mangkurat \\ Jl. A. Yani Km 36, Banjarbaru, Kalimantan Selatan \\ 2 mmahfuzhs@ulm.ac.id
}

Artikel diterima: 24-10-2019, direvisi: 23-11-2019, diterbitkan: 25-12-2019

\begin{abstract}
Abstrak
Kerajinan anyaman purun mempunyai nilai ekonomi yang besar. Salah satu kendala dalam pengembangan kerajinan anyaman purun adalah proses produksi yang masih tradisional sehingga belum mampu memenuhi permintaan pasar dan kualitas produknya yang masih rendah. Melalui kegiatan KKN-PPM mahasiswa FMIPA ULM membuat alat pewarna purun semi otomatis untuk meningkatkan efisiensi proses pewarnaan. Hasil kegiatan menunjukkan alat pewarna tersebut dapat mempercepat proses pewarnaan hingga 4 kali dibandingkan proses pewarnaan tradisional. Penyempurnaan alat tersebut masih diperlukan untuk menghilangkan komponen biaya produksi yang lain.
\end{abstract}

Kata Kunci: Kampung purun, Kelurahan Palam, wisata Banjarbaru

\begin{abstract}
Purun woven craft has a great economic value. One obstacle in the development of purun woven craft is the production process which is still traditional so that it has not been able to meet market demand and the quality of its products is still low. Through KKN-PPM activities, FMIPA ULM students make semiautomatic purun dyes to improve the efficiency of the coloring process. The results of the activity show that the coloring tool can accelerate the coloring process up to 4 times compared to the traditional coloring process. Improvement of these tools is still needed to eliminate other components of production costs.
\end{abstract}

Keywords: Purun Village, Palam Village, Banjarbaru tourism

\section{Pendahuluan}

Usaha Kecil Menengah (UKM) merupakan salah satu sektor usaha riil yang memiliki peranan penting dan merupakan salah satu tulang punggung perekonomian negara berkembang seperti Indonesia. Namun terdapat beberapa masalah dalam mengembangkan UKM tersebut.

Purun Tikus memiliki nama ilmiah Eleocharis dulcis (Heyne 1987). Masyarakat lokal menyebutnya dengan purun tikus. Tumbuhan purun tikus merupakan tanaman khas pada daerah lahan basah. Namun demikian, 
purun dianggap sebagai gulma pengganggu. Masyarakat Kelurahan Palam memanfaatkan tumbuhan gulma tersebut menjadi kerajinan anyaman yang bernilai ekonomi tinggi. Beberapa produk kerajinan anyaman yang dihasilkan antara lain: tas, tikar, bakul, topi, dan banyak lagi jenis kerajinan lainnya. Hal ini mendorong pemerintah daerah Banjarbaru mendirikan Kampung Purun sebagai salah ikon wisata Banjarbaru. Peranan pemerintah sangat penting dalam meningkatkan komoditas anyaman purun baik di pasar lokal, domestik maupun internasional.

Pengrajin purun masih melakukan kegiatan produksi anyaman purun secara tradisional. Kegiatan pengumpulan purun yang diambil dari lahan rawa yang ada disekitar pemukiman warga, penjemuran, pengeringan, pewarnaan dan penganyaman purun masih sangat konvensional. Pewarnaan purun masih belum variatif dan masih menggunakan warna purun yang masih original setelah proses pengeringan.

Peranan teknologi tepat guna diperlukan untuk meningkatakan produktivitas, jenis dan varian purun untuk menigkatakan nilai jual dari produk purun. Salaha satu teknologi tepat guna ialah dengan melakukan pewarnaan purun pada tahapan setelah pengeringan purun sehingga dapat meningkatan ragam dan aneka warna produk purun. Pewarnaan saat ini dilakukan masih secara manual sehingga memerlukan waktu yang cukup lama dalam proses produksi anyaman purun.

\section{Metode}

Alat pewarna purun merupakan teknologi tepat guna sederhana yang dapat digunakan dengan mudah. Namun demikian untuk memudahkan penggunaan maka dilakukan pelatihan penggunaan alat pewarna tersebut yang dilakukan oleh mahasiswa KKN-PPM 2019. Pelatihan diikuti oleh 10 pengrajin anyaman purun.

\section{Hasil dan Pembahasan}

Aplikasi TTG pada UMKM merupakan hal yang sangat penting. Hal ini disebabkan TTG mampu memperbaiki proses produksi dan produk UMKM. Kerajinan anyaman purun merupakan salah satu UMKM yang menjadi salah satu tujuan wisata dan ikon di kota Banjarbaru.

Seiring dengan promosi produk dan meningkatnya permintaan produk kerajinan, maka diperlukan alat-alat TTG yang mendukung produksi kerajinan sehingga dapat memenuhi permintaan. Salah satu tahap pada proses produksi kerajinan anyaman purun yaitu pewarnaan purun. Selama ini, proses tersebut dilakukan dengan cara manual dan tradisional yaitu dengan merebusnya di panci dan dibakar dengan kayu bakar. Proses pewarnaan tersebut memerlukan waktu yang lama dan kuantitas purun yang sedikit, sehingga berpotensi tidak dapat memenuhi pesanan dalam jumlah banyak. 
Untuk mengatasi permasalahan tersebut diperlukan TTG yang dapat melakukan proses pewarnaan dalam jumlah banyak. Melalui kegiatan KKN-PPM diaplikasikan alat pewarna purun semi otomatis, yang dapat meningkatkan proses pewarnaan purun.

Alat pewarna memiliki desain seperti bak (Gambar 1.). Di dalam bak terdapat alat penjepit purun yang mampu menampung 4 ikat purun, penggerak dari alat ini adalah motor dengan kapasistas 250 watt, sehingga sangat cocok dengan tegangan yang ada di rumah pengrajin. Sebagai pengganti kayu bakar, maka digunakan kompor gas untuk memanasi pewarna yang ada di dalam bak penampung.

Alat pewarna semi otomatis dapat menampung 4 ikat besar purun yang siap diwarnai, dalam sekali proses pewarnaan. Kapasitas tersebut $4 \mathrm{x}$ lebih besar dari pada pewarnaan secara tradisional menggunakan panci. Purun yang telah dijemur dan dikeringkan dapat dilanjutkan ke tahapan pewarnaan data dilihat pada gambar 2.

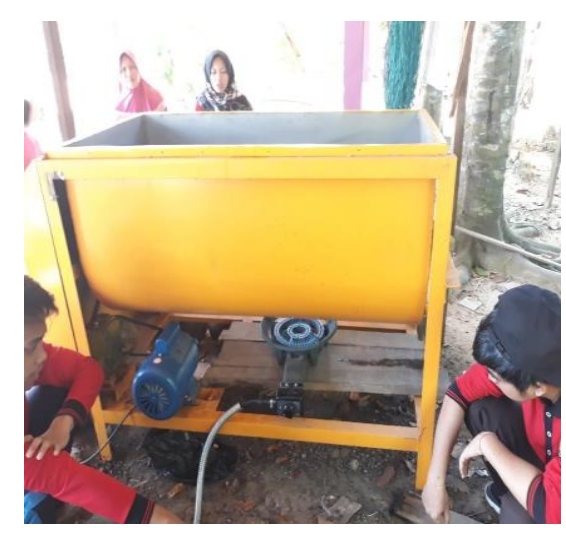

Gambar 1. Alat pewarna purun semi otomatis.
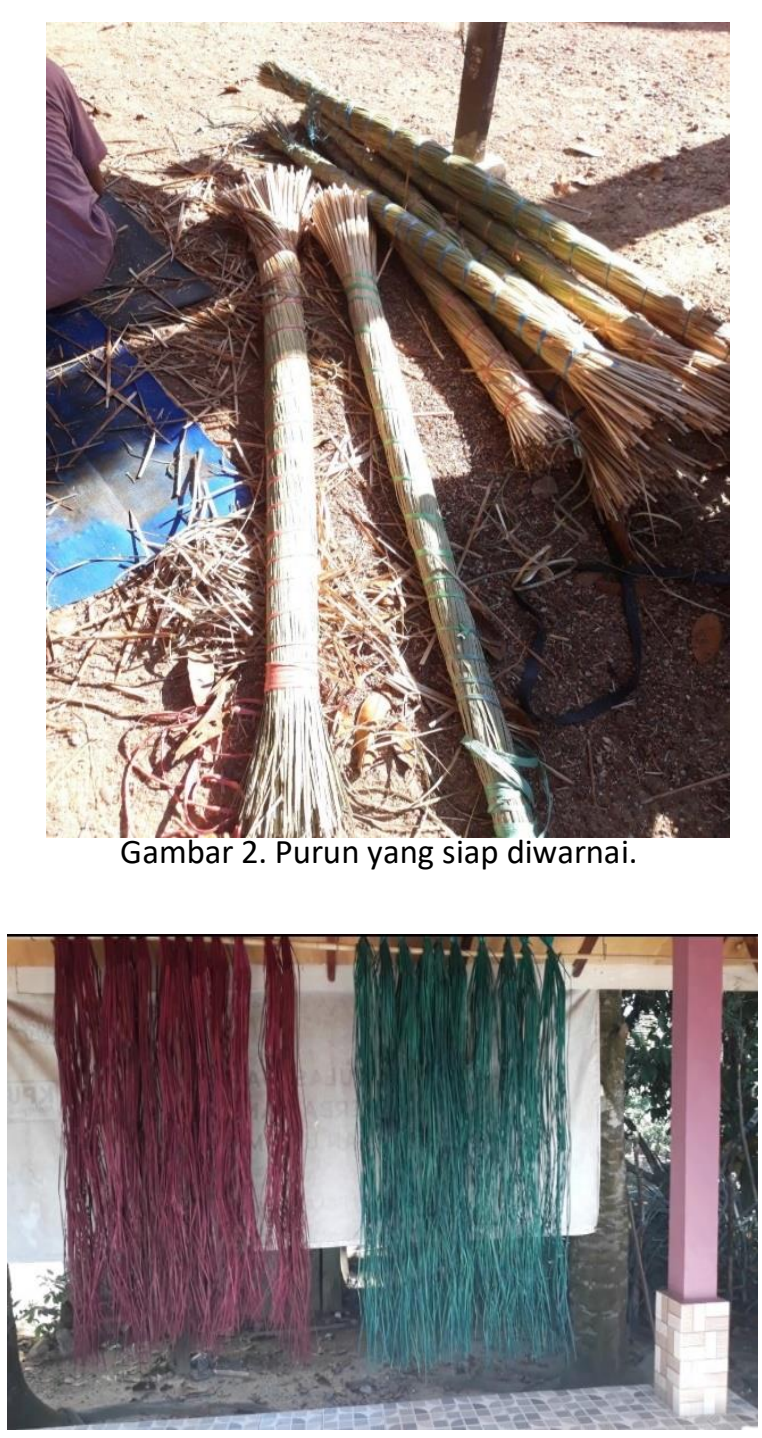

Gambar 3. Hasil pewarnaan purun menggunakan alat pewarna semi otomatis.

Penggunaan alat teknologi yang tepat guna berupa mesin pewarna purun dapat meningkatkan pengetahuan pengrajin mengenai fungsi yang dapat membantu pengrajin purun dalam melakukan inovasi dan kreativitas produk purun yang diproduksi. Dengan pengunaan mesin pewarna purun juga dapat meningkatkan nilai jual dan penghasilan pengrajin purun. 
Evaluasi kegiatan yang dilaksanakan menunjukkan bahwa penggunaan alat pewarna purun semi otomatis dapat meningkatkan efisiensi proses produksi. Namun demikian, pengrajin terkadang masih enggan untuk beralih dari cara lama ke cara baru. Hal ini disebabkan penggunaan alat pewarna memiliki tambahan biaya produksi yaitu pemakaian listrik dan gas elpiji. Sehingga masih diperlukan pendampingan dan dorongan untuk beralih ke teknologi tepat guna. Hal ini juga mendorong tim pengabdi untuk mendesain ulang alat pewarna sehingga bisa digunakan untuk beberapa sumber energi panas.

\section{Penutup}

Berdasarkan pada survei yang dilakukan selama kegiatan KKN berlangsung, penggunaan alat pewarna purun dapat meningkatkan proses produksi 4x lipat. Namun masih diperlukan dorongan dan pendampingan untuk keberlanjutan penggunaan alat pewarna tersebut. Hal ini disebabkan adanya biaya produksi tambahan, yaitu listrik dan gas LPG.

\section{UCAPAN TERIMA KasIH}

Ucapan terima kasih disampaikan
kepada Lembaga Penelitian dan
Pengabdian kepada Masyarakat
Universitas Lambung Mangkurat (LPPM
ULM) melalui SIMLITABMAS
KEMENRISTEKDIKTI yang telah mendanai
kegiatan ini melalui program kegiatan KKN
pendanaan Tahun 2019.

\section{Daftar PUStaka}

Heyne, K. 1987. Tumbuhan Berguna Indonesia. Jilid I dan II. Terj. Badan Libang Kehutanan. Cetakan I. Koperasi karyawan Departemen Kehutanan Jakarta Pusat.

Inpres No. 3 Tahun 2001 : Tentang Penerapan dan Pengembangan TTG. Laliyo LAR, Sardi S, Pomalato S. 2014. Rekayasa Implementasi Teknologi Tepat Guna melalui Pengembangan Model Pembelajaran untuk Menumbuhkan Budaya Pemanfaatan Energi Terbarukan pada Masyarakat Daerah Terpencil. Laporan Tahunan Penelitian Unggulan Perguruan Tinggi. Universitas Gorontalo.

Situmorang SH dan Safri M. 2011. Urgensi pengembangan teknologi tepat guna di kota Medan. Jurnal Ekonom. 14(4):197-208.

\section{Riwayat Hidup PenUlis}

\section{Fatma Indriani, S.T, M.I.T}

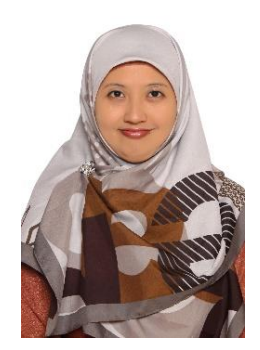

Lahir di Banjarmasin, 20 April 1984. Staf pengajar di PS Ilmu Komputer, FMIPA Universitas Lambung Mangkurat. Studi S1 Teknik Informatika di Institut Teknologi Bandung lulus tahun 2008; S2 Master of Information Technology di Monash University Australia lulus tahun 2012. 